Full reference:

Hall, S. (2012) 'The Solicitation of the Trap: On transcendence and transcendental materialism in advanced consumer-capitalism', Human

Studies Special Issue on Transcendence and Transgression, 35(3): 365-381

\title{
The Solicitation of the Trap: \\ On transcendence and transcendental materialism in advanced consumer-capitalism
}

Steve Hall

Teesside University

UK

\begin{abstract}
This article argues that a transcendental materialist conception of subjectivity can move us beyond the orthodox idealist theories that dominate progressive thought in advanced consumer-capitalism. This position can shed new light on current forms of subjectivity that seem to prefer life in consumer culture's surrogate social world rather than active participation in cultural and political resistance and transformation, which requires far more than simply 'transcending the norm'. The rebirth of creative political subjectivity is impossible unless the subject is prepared to risk a traumatic encounter with the Real, the fundamental indeterminacy that exists not in the ideal-symbolic but the material realm, and prepared to reject liberal-postmodernist identity politics to participate in the construction of a coherent alternative ideology.
\end{abstract}

\section{Key Words}

Subjectivity; transcendence; catastrophism; pseudo-pacification; consumerism; transcendental materialism

\section{Introduction}

From a point in high modernity when the ancient regime's symbolic order began to bow out and make way for generic liberal individualism, we have lived in hope that somewhere on the very bottom of the human deep there is a creative life-force, a natural drive compelling the individual to shake off institutionalised authority, the decaying coagulation of history that, as Karl Marx (1963) said, weighs 'like a nightmare on the brain of the living'. This individual is, we hoped, able to separate itself from the conformist herd and become an authentic human being; a self-governing, self-actualizing and self-selecting moral agent. Individual freedom is thus wrapped up in the fundamental philosophical question of transformation and progress, how to move from what is to what is not (Badiou, 2002). The notion of transcendence, in what we have often understood as its idealist and materialist dimensions, should not be thought of as an end in itself but simply a means and a pathway to freedom. However, transcendence and progress have not always had it their own way in philosophy, even amongst those branches that at the beginning of the Enlightenment project were thought of as 'radical'. Spinoza, for instance, drawing from Aristotle, understood that the human being seeks to transcend what is but is also motivated by the counterforce of conatus, the need to defeat life's bothersome stirrings and seek comfort, calm and safety in a condition of homeostasis (see Damasio, 2003). We could see this as perhaps a rather Epicurean yearning that seeks to attenuate and defuse the extreme irruptions of what Hegel was later to call the Night of the World and Lacan the Real - a concatenation of externally and internally sourced stimuli that stir the senses into life but which, because they cannot be understood by means of a cohesive set of symbols, are pre-symbolic and thus initially and inevitably traumatic- and thus return to a womb-like calm. Freud further developed this notion as the basis of the nirvana principle and death-drive, the urge to destroy what threatens us before we can understand and deal with it in a reflective and rational manner, thus returning as quickly as possible to the original undisturbed state. Indeed, communities can become insular and womb-like, protective life-support systems whose members rely solely on the community's venerable symbolic order to both explain and repulse any threat that faces them; a recourse to what, before most of us tacitly agreed to obey the liberal-postmodernist command to use non-Marxist language, we used to call ideology. It is always difficult to convince individuals that it is a good thing to dismantle and transcend that which they have come to know as their sole means of comfort and protection, especially when, in the age of advanced mass communications technology, existential threats can be mediated, inflated and diffused at will to throw the community into a state of alert. In this climate the emotions and the rational faculties can combine to perceive transcendence as a poor option. 


\section{Systemic Instability and Anxiety}

Mobilising the 'politics of fear' to stir up panic, hatred and the required form of aggressive or punitive reaction amongst the community is an ancient and venerable psychopolitical technique, but it's not the only one. Because the principal objective is collective conatus rather than a permanent state of alert, the community's ruling elite does not wish persistently to stir up fear, which in the long-term would be disruptive and delegitimising, perhaps even fatal to the continuity of the elite's ideological community itself; best not to 'cry wolf' too often. It's also possible that the 'politics of fear' is a misnomer, and far more effective in this political game is objectless anxiety, the maintenance of a vague undercurrent of unsymbolised apprehension in which almost any object of fear, internal or external, can be manufactured to suit specific circumstances and political objectives. Not that this requires too much conspiratorial effort; global capitalism -prone to periodic economic crashes, and characterised by precarious livelihoods and everyday socioeconomic relations energised by a notably volatile and unforgiving yet functional form of competitive individualism named elsewhere as pseudo-pacification (Hall, 2000; 2007; 2012)- is the perfect platform on which a condition of low-key objectless anxiety can be permanently maintained with very little positive mediatory effort. The ideological effort required is largely negativistic; a relatively simple task of dissuading the population that the system's underlying corruption and instability is what everyone should really be worried about. A little while ago neoliberal capitalism's advocates told us in no uncertain terms that, in Baroness Thatcher's famous words, 'there is no alternative', yet recently, in the form of the Credit Crunch and its social aftermath, we have been reminded once again of just how unstable and destructive it actually is. Consequently, the volume of this ideological dissuasion is currently pumped up fairly high.

This unstable system produces a multitude of very real threats, misnamed as 'risks' by risk managers, the new apparatchiks of the post-political era, who underestimate the impacts of events as they ideologically isolate them and treat them as disconnected items on a managerial agenda. The threats that prick our senses enjoin us to imagine, without the aid of either approved or autonomous collective symbolism, their future impact on our lives. When they are not to the elite's liking as ideological vehicles, the post-political community, confident in the objective probity and durability of its way of life, will always try to convince its members that nothing is actually happening, other than some attenuated paramorphic substitute that can be explained away by official ideology and dealt with by extant institutions of order and control. For the ideological community, reality must always be symbolised and explained to its members solely in this way. Perhaps then, right at the core of things, because the transition from objectless anxiety to objective fear carries with it the greatest political risk of all that a majority or perhaps even an influential minority of the population might become confident in their knowledge of the real source of fear as the unstable and brutal system itself- we are not really dealing with the spectacular politics of fear or even the politics of distraction, but the relatively low-key politics of sustained objectless anxiety as the platform upon which objects of fear or security can be constructed at will.

\section{Catastrophe}

In stark contrast to Spinoza's conatus, a constant yearning for homeostasis, the entropic stillness and protection of the womb simulated in our everyday psychosocial lives, we find Bergson's more dynamic and individualised concept of élan vital, and Nietzsche's extreme instinctual drive, a force of nature he enjoins us to unleash without further ado as the categorical imperative of eternal recurrence, the deontological command to live life to the full in a way that we could imagine would still excite our sensibilities even if we had to live it over and over again in exactly the same way for all eternity. However, both rely on what Freud was later to call sublimation, the transformation of the instinctual drives to symbolic form, to live life as art and culture so that the drives' potential for violence can continue to be pseudo-pacified in the way that modernist-capitalist life demands (see Dews, 2008; Hall, 2012). Only thus are we able to pursue in a civilized way the desires the life force stokes up inside us and the visions it puts before us. We yearn for the life-force to put wind in our sails and blow us on a course of transcendence, but we do not want its real violence, which is inevitable, because the lifeforce must always confront the resolute oppositional forces of tradition, and it is thus both creative and destructive when enacted in reality. If the life-force chooses collective reality as its battleground, it must clear away the decaying structures of ancient regimes and somehow neutralise those individuals who would defend them with their lives. The violent English Civil War and French Revolutionary Terror are but two illustrations of this principle, and Lenin, the quintessential materialist revolutionary, sought to clear away the physical, political and socioeconomic structures of the prehistory of class oppression in one fell swoop; in doing so he laid the ground for the Stalinist brutalities that were to follow (Pannakoek, 1975). So, better for everyone that this is done not by the masses in the real world of political economy, but by the individual in the world of 
culture and ideas, one of the reasons why Nietzsche, despite still carrying a bad name for some (see Bull, 2000), eschewed politics, hated the imperial state with all its internal and external violence and regarded its apparatchiks as dangerous buffoons.

Indeed, the catastrophic 'short twentieth century' (see Hobsbawm, 1994) was a product of brutal imperial states adopting powerful ideas, ranging from Leninism to atavistic racist-nationalist fantasies and various personality cults, and attempting to implement them with a 'passion for the Real' (Badiou, 2007). Such was the magnitude of the ensuing catastrophes that classical liberalism, despite being the failed system out of which some of these monstrous movements grew, returned after World War II to enforce its fundamental principles of hedonistic calculative individualism, negative rights and market economics. Of course we had inherited the knowledge from our past thinkers that individualism could become competitive and anti-social, that the tenet of 'harm' that placed Mill's (2006) essential civilizing boundary around our positive rights to freedom was nebulous and open to political manipulation, and that the market was unstable and prone to crashing and inflicting cultural decadence and socioeconomic misery on populations. However, classical liberalism's Restoration in the modified form of neoliberalism (see Badiou, 2007) was no idealist project; in fact quite the reverse, and the struggle of the cave-dwellers to approach even shadowy imitations of Plato's ideal forms was replaced by a cool-headed utilitarian pragmatism. It inspired no one and led nowhere, but in the wake of such catastrophes it was the safe option. Thus we entered the post-war continuum of catastrophism (Hall, 2012), a strange and hitherto unseen functional combination of conatus and the life-force, where the sole direction in which libidinal energy was allowed to flow was back towards conatus, yet at the same time conatus had to be removed from the core of the communal-political unconscious -in other words the community's ideological tradition- and cast out into a strangely externalised culture of fluid texts and discourses that was to be maintained, along with its subjects, in a state of permanent flux. The underlying culture of objectless anxiety was given its dominant object of fear-totalitarianism- which is sustained by the constant commemoration of its historically specific evils in a hegemonic cautionary tale. This culture exhorts us to join in the endless Derridean dissent that must automatically and without end dissolve and reconstitute everything that comes into existence as it emerges in our imaginations, symbolic life or socio-political reality. Ferrell (2007) inappropriately compares this temporal and indiscriminate liberal-postmodernist 'criticism of everything existing' to the work of Marx, who was of course far more discriminate as he celebrated peasant customs (Marx, 1842) and targeted his criticism directly we might say with surgical precision in his later analyses of the intricate workings of Capital itself- at the bourgeois world as it existed, as the first step towards the systematic transformation of that world. The liberalpostmodernist variant is of course not transformational but cautionary, apolitical and self-negating, the product of a tacit yet singular, foundational and very potent objectified fear rather than a positive vision of the future, and as such it can lead nowhere but the totalising scepticism and anhedonic nihilism we see in the culture that attends the post-political world today (Dean, 2009; Fisher, 2009). Although excessively proud of its radical credentials, its cautionary and piecemeal foundation fits in neatly with the more mainstream philosophy of neoKantian moral constructivism, advocated in sociology by Weberian-inspired constitutional theorists such as Giddens (1984), and the post-political practices of social micro-management. This position is still dominant despite the fact that since its adoption and implementation by the governments of Blair, Clinton and Obama, the 'third-way' political doctrine that emerged from it carries the burden of hypocrisy and failure in its attempt to manage life, offer comfort and sustain conatus in the midst of today's geopolitical and economic volatility. It would be difficult to put forward an honest argument that a vitalistic form of transcendence that could be applied to our collective life would ever be allowed a place on the agenda. If the creative life-force exists at all, it does so only in the psyche of the isolated individual, and that's where our post-political managers would like it to remain.

\section{Out of Catastrophe?}

If we are to believe that the life-force exists, that somewhere there is some sort of urge welling up from the deep to motivate the individual to take a leap of faith and transcend what is to move to what is not, perhaps even carrying with it the potential of aggregating into some Hegelian movement of the collective spirit, we must temper this optimism of the will with at least some pessimism -or, better, some realism- of the intellect. This must be grounded in an understanding that, should this impulse or something like it really exist, it currently operates in the hegemonic climate described above, a backdrop of sustained objectless anxiety on which only one object of fear is allowed to be brought into relief, that of the possible return of totalitarianism -even though it is the last thing anyone wants- in the event of the return of politics as a mass response to neoliberalism's current crisis. Before assessing the ability of the life-force to thrive in this restrictive environment, let's take a brief look at it through the eyes of one of its most eloquent advocates in the social sciences. For Ronnie Lippens, 
(2012), transcendence is inextricably tied up -we might say dependent upon- the human ability to create. A motif of educationalists at least since Dewey, the creative capacity marries freedom to control, and rids control of the notoriety it has gathered in many of the less sophisticated liberal discourses. In an interpretation of Les Cyclope, a painting by Paul Rebeyrolle, Lippens argues that the elusive Enlightenment reward of sovereignty is the capacity for control over emergence, which in Rebeyrolle's work:

... implies creative intervention, or invention. It is the capacity to create. He who is sovereign [...] is he who has the capacity to create. Creation is the name of the event whereby control over emergence is exercised. Creation is not just a process. It is also an intervention. It is, indeed, invention. To create, to bring newness into the world, to add to life, all this implies a capacity to not only sense the raw laws and codes [...] The event of sovereign creation is an event whereby laws and codes are sensed and reflected upon, and subsequently transformed in a particular direction [...] Like Nietzsche's superhuman though, Rebeyrolle's sovereign is aware of the tragedy of life. He realises that in order to be sovereign, and that in order to control emergence, one must relinquish all radical escape from law and code. Sovereign is he who knows that the issue is not to elude all law and all code, but, rather, to intervene in them, creatively (ibid.).

As a social scientist, Lippens is aware of the need to move beyond the notions of free choice proposed by orthodox liberal philosophers (see for instance Nussbaum, 1992), for whom it as an exclusively private affair whose social outcomes and influences remain obscure, to the extent that one gets the impression that the discourse carries a preference not just for indeterminacy and fluidity but also the minimisation of these outcomes and influences. This is unwanted elusion par excellence; advocating neither allegiance to nor transformation of traditional social structures and organic cultures, a tacit principle that prompted Žižek (2006) to condemn such mainstream liberalism as the slightly more humane and progressive wing of conservatism, or 'liberal-conservatism', to use his term. However, creative intervention in law and code could mean anything from a Rawlsian micro-reform in healthcare legislation to the establishment of Year Zero, and Lippens pulls no punches as he reveals the extent of the political ambition he attributes to creative sovereignty:

But the desire and will to absolute sovereignty keeps restlessly boiling underneath the illusions of late modern capitalism. The desire to resist all code and the will to achieve total control over emergence (however illusory, however imaginary this desire and this will) are only a situation away (ibid., original italics).

Lippens is tacitly agreeing with Žižek that to avoid engagement with the symbolic order is to simply excuse oneself as one conforms, and the real issue we must confront is not Nussbaum's private choice but creative resistance. Lippens's optimism of the will is also tempered by an intellectual appreciation of the difficulty the latent proto-sovereign will face as it creates itself in the midst of and in opposition to the hegemony and the seductive simulacra of advanced capitalism's veteran cultural system:

Not that this is easy in a culture as utterly ubiquitous as late modern consumer culture [...] the latest phase in the "pseudo-pacification process", i.e. "neo-capitalism", not only fails to pacify, its market dynamics actually thrive on the constant production of a multitude of transgressions and corresponding practices of control - provided, of course, that those transgressions and controls are fully embedded within the code of the "neo-capitalist" market logic (ibid.).

However, Lippens is undeterred by communicative capitalism's ability -honed in the post-war period of massmediated consumer culture- to manipulate the codes of transgression and transcendence around the powerful icon of 'cool individualism', which attempts with a good deal of success to absorb the individual in consumer culture's seductive simulacra and distract it from creative intervention in law, code and the often mundane reality of socioeconomic life (Dean, 2009; Hall et al, 2008; Frank, 1997). He is convinced that the sovereign individual can reflect upon and turn away from such incorporative and generative distractions and draw from the depths of the human well the life-giving water of creativity:

[I]n the post-war form of life par excellence, the desire and will to absolute sovereignty is only a situation away. The aspiring absolute sovereign dwells in an imaginary zone before or beyond all code, before or beyond all distinction, and in that zone he may, or may not, choose to submit to or adopt or indeed contemptuously reject particular codes as he thinks fit [...] these strategies reflect Hesse's twin strategies of immersion into immanent emergence on the one hand and detached reflection on the other. We now know that Rebeyrolle suggests a third: creation, i.e. the negation of law and code through the 
production of the new. Rebeyrolle even went as far as to paint, in 1999, a complete series on the topic of neo-capitalism (i.e. the aforementioned Le Monétarisme). In the creative process suggested by Rebeyrolle, the simple codes of neo-capitalist reflection and consumerist desire, they too, end up being crushed to dust. "Neo-capitalism", and "consumerism", as codes, are only a situation away from the aspiring sovereign's will and desire [...] In the sovereign's imagination, that is (Lippens, op. cit.).

Lippens is right that social transformation is not possible without the reconstruction of laws and codes, and that the individual -and by extension, possibly, a collective of individuals participating in a democratic order- has the innate creative capacity to do so. He is also right that creative capacity is energised and formulated by the relentless visionary forces of the imagination. Here he presents a force that has as much to do with Blake's 'arrows of desire' as with Bergson's élan vital or Nietzsche's Übermensch. Blake presaged Hegel, Freud and Lacan in understanding that human desire is orientated outwards to the external social world; he imagined the 'building of Jerusalem', an initially radical thought that was unfortunately hi-jacked as a Tory refrain. This Lacanian 'extimate' space, the nexus between the internal psychic and external social world, is the location where desire's objects are created, mediated and affirmed; by its very nature it is a two-way conduit, a 'border crossing' between emotional (libidinal) energy and the socio-symbolic order that gives shape to it. This potent nexus of desire, creativity, choice and affirmation, in the same way as Wittgenstein's language, can never be private; those who wish to transcend must find 'partners in crime' lest the spirit die or turn inwards to a selfaffirming interior cycle and produce little more than quaint eccentricity. Whereas Lippens is unerringly correct to locate the first step of the life-force's emergence as the human imagination, his optimistic expectation that the act of creative transcendence is always a 'situation away' ignores the necessity of passing through a complex psychosocial process and a vast and hitherto dauntingly difficult order of sociosymbolic meaning, both of which are predicated on a dialectical and unavoidably political struggle for social meaning (Jameson, 2010). The fact that Lippens inserted that last telling phrase -that will and desire reside in the imagination- tells us that he is aware of a great difficulty that confronts each individual despite the latent actualising power that resides within, but the concept of the 'situation', the motif of a failed countercultural movement that has passed into history, understates that difficulty.

It is difficult to argue against the notion that the human being possesses a great capacity for imagination and creativity, and there is no reason to do so, or to hesitate from celebrating its heartening if rather uncoordinated and ephemeral manifestations. The imagination, however, even though it dreams of sovereignty and draws upon powerful energy, is a means of forming ideas about what is not available to the senses, or what is available to the senses and cannot be explained by extant symbolism. Lippens points our small band of intrepid but rather weary social/criminological theorists in the right direction, one that is far more intriguing and potentially fruitful than that imposed upon us by the current neo-Kantian and Weberian liberal orthodoxy, represented by Giddens (1984) and others, who cheerlead the individual as the already fully-formed reconstitutive moral agent acting in the name of piecemeal progressive reform to humanise our existing institutions and protect a minimum standard -and nothing more!- of human rights. Their failing is that they cannot detect -or choose not to- the smell of functional exploitation, corruption and irreversible decay at the core of a system whose psychosocial motor is little more than 'institutionalised envy' (Žižek, 2010a). How many times must rogue bankers and corrupt politicians gamble away or embezzle the wealth created by working people, how many times must these plutocrats force the same working people to pay for their indiscretions and send them into military confrontations to lose their lives, and how many times must vulnerable people be beaten to death by thoughtless and conscienceless assailants on the streets of post-industrial wastelands before liberal theorists admit that right at the core of our way of life there are forces and structures with which -at least under prevailing political conditions - the creative moral agent and our current institutions are simply unable to get to grips? Like all those with power and influence, when reminded of fundamental forces and structures that are regarded as irreplaceable, they politely but firmly change the subject. In one of the most transparent and guileless disclosures of the catastrophism and fatalism that underlie orthodox liberal theory, Turner (2010) warns us not to look too deeply into ourselves and our way of life lest we succumb to the wicked notion of imposing universal ideals on reality and subsequently descend into totalitarianism, but instead to indulge in the construction of the self as a work of art as the lone individual faces the inevitable failure of all social systems. This romantic-solipsistic fatalism has more to do with Judaeo-Christian folklore than with philosophy or social science, and Lippens quite rightly insists that we dig down below the surface that liberal-postmodernists would prefer us to regard as the totality of life, through the hard ground and sweaty earth to the foundations, the place where we have all been warned not to go. 


\section{Towards (a) Symbolic Order?}

But, as Lippens knows, this is not the first time we have been there. The caverns are littered with the abandoned detritus of earlier potholers. Somewhere down there dwells the desire/imagination/creativity nexus, but, because we experience it in so many diverse symbolic forms on the surface, we are still not sure what its wellspring looks like; élan vital or the transcendental instincts of the Übermensch? Possibly, but when Jacques Lacan followed Freud to plumb these depths he seemed to discover not simply a natural positive force but a dynamic system, a milieu of tensions and conflicts centred around a void; at the deepest core of the human subject there was absolutely nothing at all. The erotic libidinal force is of course present and indeed very potent, but, beyond its crude sexual roots, it is amorphous; creativity is always possible, but it is predicated on something even more primal. All human beings are born prematurely and totally helpless, and from the moment of birth the infant is tormented by a terrifying pre-symbolic sense of the entire absence of an ability to survive without the aid of others of the same species, who, along with the infant itself, can eventually, once the primary narcissistic relation is broken, be recognised in a symbolic order comprehensible to all. Lacan was a biosocial essentialist, and positing him as a theorist who saw the shifting sludge of language at the root of the human being -although he did have a very important place for structured symbolism as the medium through which the individual can establish herself in the social- is a post-structuralist convenience. When compared with our primal need to belong to the social in the first place, our urge to transcend it pales into insignificance. Not so, however, our collective need for the social itself to transcend historical forms that despoil our relationships within it, fail to nurture sociable individuals and place less aggressive and more vulnerable individuals in jeopardy (Adorno, 1973; Dews, 2008). The subject is at its core, as Lacan knew, driven by a sense of lack; down there at the epicentre is a void, an abyss that exists as the terror of the Real in the pre-symbolic Imaginary, which by its very nature has no initial idea of what it requires to fill it and end its torment. It is not a positive monadic energy source like the core of an atom or the release of chemical agents in the neurological system, but a gap prone to irruption, a pre-symbolic neural convulsion of negativity that can be assuaged only when the individual's place in the social is assured by careful gesture and symbolism. When young men and women congregate in urban gangs, it signifies a way of dealing with the absence of a nurturing socio-symbolic world that engenders a sense of identity, security and trust, and the substitutive presence of the fraudulent pseudo-pacification process, a hostile and unforgiving quasi-social competition whose codes and rules, unable to guarantee worthwhile participation and maintain non-violent order and a sense of justice, are in the process of breaking down (Hall, 2007).

Lippens is right to insist on the reflective moment -and we have no reason to doubt that reflective consciousness plays a vital role- but if Hegel's (1979) famous dictum that self-consciousness is desire itself and attains its satisfaction only in another self-consciousness (see also Pippin, 2011), the individual can only recreate itself and become 'for itself' in some sort of erotic relation to the collective, to other individuals. So, somehow, the collective must also make Lippens's leap, because to become a reflective being the individual needs affirmation and symbolic tools that are available only from the collective. One can imagine a crowd of teenage boys daring each other to jump off a bridge into a river, trapped in inertia as each goads the other to go first, before finding the sole solution that all must agree to do it before even the bravest will jump first. Only in that moment of unification and affirmation can the jump become symbolised as possible and become possible; without this, even if a brave individual jumps first, there is no guarantee that the rest will follow, or that anyone will regard the jump as a truly symbolic act. This presents us with a qualitatively different problem. In the post-war era the Hegelian dialectical struggle for the 'third space' of ideas that inspire a new Zeitgeist and the Marxist dialectic of class struggle were replaced by a flattened-out non-dialectical struggle between the individual and the state, replete with a new demonology (Bosteels, 2010). Such was the fear of the universal political project in the wake of the catastrophes described earlier that we had to learn to find comfort in that which had been throughout history our major discomfort, the loss of universal meaning. Our postmodern heroes became those who could lead us there, and of course keep on leading us there because no actual destination exists; a guaranteed job for all eternity, one might suspect. For Badiou (2007), the history of the transition from high to late modernity is a journey from the Imaginary of Blake through the Symbolic of Hegel and Marx to the passion for the Real, and that's where -largely because of its own impatience and the brutality it unleashed-it fell as it abandoned its principles in the short-cut to their achievement. This abandonment, of course, made the project's achievement impossible. However, despite this catastrophic failure, without an alternative ideology that can inspire hope, counteract lack and validate creativity, thus providing an emergent symbolic order to operate and experiment in as a communicative and inspiring social form, the creative drive to transcend remains amorphous, atomised, sporadic, directionless and impotent; those who jump off the bridge do so alone, unnoticed and uncommemorated. It fails in the essential task of establishing a symbolic order -the active constituent parts of 
which Badiou (2002) names as love, art, politics and science- that can ensure its own inspiration, validation, reproduction and growth.

Thus, by dismantling and quarantining its socio-symbolic incubator and its political vehicle, liberalpostmodernists neutralised the life-force. However, after the Sokal affair their credibility is shattered and their time is up; very few people nowadays want to be known as 'postmodernists' (Žižek, 2010b). An alternative critical view -now gaining momentum as the results of all this relentless and proliferating cultural dissent begin to disappoint- is that this post-war faux-radical current has neutralised the life-force even more effectively than the ancient regime's oppression, by endlessly sublimating and diffusing it in a post-structural language-game whose goalposts constantly shift, where dissent is compulsory and interminable yet the meanings created by the rapid procession of counter-hegemonic discourses can never be settled on for long enough that they might inspire and promote any meaningful socio-political action. Worse, they can be co-opted, and, worse still, they can be manufactured as pre-emptive master signifiers in consumer culture by the advertising industry. Thus, all we did was to dislodge the womb from the core of the ideological community and scatter the seeds of the lifeforce to the far reaches of a cultural system in permanent flux, and the political-ideological unconscious that once energised each individual who entered its symbolic order was flung out into Foucault's 'positive unconscious', the dark sides of a multitude of apolitical discursive objects as they appear and disappear like stars twinkling in the outer limits of the galaxy. This was not an intellectual move for the sake of progress, but for a new and more effective quarantine for both conatus and creative energy, for the permanent externalisation, disruption and neutralisation of the confident subject inspired by 'passion for the Real' (Badiou, 2007), which, we catastrophists thought, had given us little but death and destruction.

Such passion was replaced by identity politics, but this engenders a subject that is far more vulnerable to consumer culture, not simply to assimilation but to manufacture. The real economy -not the casino of finance but the sector that produces and distributes real goods and services- requires constantly increasing demand to stimulate production. Alongside capital controls, increased demand was the fundamental principle of the Keynesian rescue act after the Great Depression, and of course demand required a larger money-supply and increased consumption. Consumption is now so vital that it constitutes 70 per cent of the current US economy, and 'consumption fragility' is, alongside 'financial fragility', one of the two fundamental factors that can tip the market economy into an epic recession or depression (Rasmus, 2010). The enthusiastic consuming subject, with its primal sense of lack constantly provoked, inflated and denied alleviation and maturation by the remorselessly efficient and inventive advertising industry, is not simply an effect of post-war economic dynamics but the essential force at the epicentre of the system. With attention focused disproportionately on an emerging 'teenage' market full of young people with disposable income -later to mutate into the 'tweenie' market as younger children were targeted (Smart, 2010)- vast amounts of effort and money were invested in an advertising industry whose task was to place before the individual a spectacular and unending procession of fashions as pegs on which new but effortlessly disposable identities could be hung. This industry was a large stone that, thrown with sufficient power and accuracy, could kill two birds. Firstly, ensuring the expansion of demand, and, secondly, replacing political subjects - whose potentially dangerous identities had been since the era of high industrialism grounded in the mythology and politics of class- with the deracinated, depoliticised and cosmopolitan subject of consumerism. Identities based in class struggle, the nation and the "passion for the Real' were to be abandoned; this is how we were to achieve peace and progress and discover new forms of sociability. In terms of the ability to foresee trends in 'youth culture' and thus pre-emptively manufacture identities by appealing to the proto-subject's sense of lack and its primary narcissistic solution, consumer culture eventually became the most adept operator in the task of subjective formation in the deep hollow core of the psyche, commandeering the creative process at its very roots (Hall et al, 2008). The descent into apolitical aggravated shoplifting that, after the initial trigger of a clear-cut injustice committed by the state against an individual, characterised the English consumer riots in August 2011, does not of course bring closure to the debate, but it casts into doubt four decades of liberal-postmodernist thinking, which celebrated the individual's creative ability to rework consumer symbols into cryptic codes of autonomy and dissent.

\section{Transcendental Materialism}

The dismal diagnosis is that since the so-called 'cultural revolution' of the 1960s we have transcended nothing. In fact we appear to be far less subjectively creative, objectively aware and politically inspired than those who populated previous radical movements (Hall et al, 2008, and see Rose (2002) for a history of British workingclass radicalism). Perhaps we had made a fundamental error in following Nietzsche's reliance on spontaneity and collapsing creativity and vitalism into naturalism (see Dews, 2008). Simply claiming that things are the 
inverse of the way we tend to think of them at the moment can, usually and quite legitimately, be dismissed as contrarian sophistry. However, given the ideological-subjective durability of the consumer capitalist system which rumbles on and maintains great allegiance amongst global populations despite its instability, destructiveness, vulgarity and gross inequalities - is it possible that we have got this foundational relation the wrong way round? Is it the neurological system, not the symbolic realm and the creative will, that is both active and flexible?

To help us think through this conundrum, the philosophical position of transcendental materialism (Johnston, 2008) returns us to the body as a genuine neurological and sub-symbolic object pulsating with energy. No discourse, Cartesian or externalist, has satisfactorily answered the question of how our supra-material subjectivity actually arises immanently from its material grounding in the biological world, a failing that hands over to both biological positivism and transcendental idealism their most valuable hostage. Following Lacanian psychoanalysis and its precise exploration of how the basic constitution of the pre-symbolic neurological system is riddled with multiple antagonisms, conflicts and tensions, transcendental materialism follows recent developments in neuroscience and continental philosophy to posit the human body as a hard-wired mechanism, but hard-wired specifically for dysfunctionality and plasticity, vital prerequisites for the adaptability of the weakly evolved and equipped human being forced to live in multiple environments. Over time this plasticity became manifest as an immense diversity of emotions, sensibilities, intuitions, linguistic concepts and physical capabilities (Damasio, 2003; Johnston, op. cit.). Our original, abject and terrifying state of pre-maturational helplessness means that the act of denaturalising our physical selves into dematerialised forms of subjectivity is natural. This is the sole, primary ontogenetic determinism we have to deal with. It is as soft as soft determinism can get, but it still operates beneath will and consciousness. However, once dematerialised, proto-cogital forms of subjectivity resist re-assimilation back into the corporeal realm, and this is the basis of the 'third space' that subjectivity and its basic post-libidinal but pre-symbolic energy occupy. The whole concept of 'embodiment' along with its variants such as bio-power, subjectification, normalisation, habitus and so on- is highly problematic, but equally so are the concepts of naturalism and unrestricted transcendental idealisation.

Oddly enough, the hand of potential collegiality has been offered by natural scientists, many of whom have rejected hard determinism. For instance, Richard Dawkins's (1989) concept of the meme connects the biological being, as far more than a functionalist-survivalist machine, with the socio-symbolic world. Although, like genes, their tasks are replication and mutation, memes are immaterial, independent from function and able to be manipulated by conscious agents aware of their own interests. Thus memes are capable of replicating both functional and dysfunctional units of information and being resistant to mutation. Systems of memes are of course ideologies. Although these ideologies can be functional to social coordination and therefore to survival, their ability to replicate themselves as a dematerialised system means that they can persist even when the original material conditions in which they were at least satisfactorily functional -but not necessarily fully functional or ethico-socially just- have disappeared. Thus their intrinsic flexibility and reproductive independence can produce a rigid inertia when they become detached from their precipitative conditions of generation. In a fundamental counter-intuitive reversal, it would appear that it is the body and its neurological system that is reflexive and our symbolic life -even in 'enlightened' liberal-pluralist forms that pride themselves on their reflexivity- that is rigid. Our symbolic life is prone to 'deaptation', where an initially functional and adaptive memetic strategy becomes actively counterproductive in a new environment (Johnston, op. cit.; Blackmore, 1999). This reproductive independence is the means by which ideology can flourish and overwhelm reality and our more direct perceptions and conceptions of it. Hegemonic ideology, by its very (un)nature, can insulate itself from major shifts in material conditions and the immediate sensory-ethical aftershocks they provoke in us, which, should they ever elude this ideology, might precipitate a shift in socially accepted symbolism, rational analysis, politics and collective direction. Liberal-postmodernist catastrophism has upstaged conservative hegemony by permanently separating the material and the symbolic in such a way that it has disabled the vital communicative-adaptive nexus that exists between them. In the parlous condition we have inherited we have little choice but to return to subjectivity.

Here we hit another major obstacle. In the well-established Kantian continuum, the moral-constructivist dimension of the overall liberal project, subjectivity is quarantined in a realm that transcends the material and is thus condemned to disinterested reflection. The ideal, we are told, can only think and speak of itself, and individuals can think only of others' thoughts. When we grapple intellectually with real nature we produce nothing but falsities. Lippens's (op. cit.) combined Bergsonian and Nietzschean way out of this Idealist stricture is to posit the individual's natural drive to create, to exert sovereign control over emergence, thus channelling this urge through the imagination and outwards to the reconstitution of the symbolic codes that govern human life. But does this capture the true form and direction of this energy and the relation between nature and spirit? 
When Hegel (1979) claimed famously that 'the spirit is a bone', he meant that the subject is not separate from substance, and its reflections are inscribed and functionally operative in the ontological structure of real nature. The Lacanian concept of the subject divided against itself and constitutive of a third realm of being beyond the material and ideal has been followed up by Žižek (2000; 2006), who combines German Idealism and psychoanalysis. By locating these two positions against a backdrop of the most current and sophisticated conceptions of matter and energy, Žižek's subject is brought into being by a burst of dialectical energy as the indeterminate material subject is cast out into a determining set of symbolic coordinates in the external world. In this explosive Oedipal eruption there is simply no time for creative reflection to take place before the subject is flung out of its narcissistic cocoon into a web of key identificatory images and words in the social world, the ideologically constituted symbolic order. It all happens before we know it, and there we are. The potentially unlimited possibilities of the indeterminate reality of being become the reality constituted by a symbolic order, confirmed and reproduced every day by the gridlocked social and economic practices of experiential reality and hegemonic political power.

In the initial formation of the subject, there is simply no time and no mechanism for the creative reflection that Lippens demands. Only after the subject has been through this identificatory process can it return inwards, now equipped with the necessary symbolic tools to reconstitute and consolidate its identity in the neurological circuits of its material body. Inside and outside become one realm of being and becoming, the Lacanian 'extimate'. This initial identity is not entirely fixed, but it cannot be unfixed unless it passes yet again through a similarly traumatic process in an alternative symbolic order, which must then battle to create an alternative practical reality to ensure its reproduction. Thus subjectivity and politics are interdependent. The liberalpostmodernist left's tactic of haranguing the initial subject for the sin of expressing conservative tendencies and failing to transform itself, whilst at the same time avoiding confrontation with their own prejudices and cancelling outright the construction of the vital alternative symbolic order, is the most counter-productive and downright alienating political tactic one can imagine. However, to create these alternatives, dialectical being must make a traumatic return to its own fundamental negativity, the radically indeterminate being immanent within its material reality at the deepest level, to burst forth yet again to disturb the status quo of the existing order and create space for its own subjective freedom. The subject cannot find its indeterminate freedom in language, image and discourse -which, despite the intellectual gymnastics of the post-structuralists, are not intrinsically flexible but the mechanisms of determinacy and entrapment- but only in the 'extimate' realm, inside/outside itself, in the space of its own void, which is the receptacle for the ideology it must escape. Although it can never be entirely free, it can eventually find itself in an unfree symbolic socio-cultural system made by itself and like-minded others (Johnston, op. cit.). What for Lippens is a linear outward movement is in reality a circular return to the inside and back out to an alternative socio-symbolic order. To expect individuals to perform this whole traumatic manoeuvre on their own without the support, anticipation and affirmation of others is to expect too much.

To change itself the subject must struggle free from its symbolic fixings in an initial ideological battle of thought against the provisional yet durable determining symbolic systems and forces that constitute the integrated whole of the prevailing ideology; the what is, of which liberal-postmodernism is simply a novel and efficient variant. The tumultuous physical contours of the brain shape experience and symbolism, but only after this successful battle with ideology can the provisional being feed back to shape the contours of the brain itself. Thus Real and Ideal combine in dialectical tension to create the 'third space' of structural dynamism we call 'subjectivity'. This circle is difficult to break, but according to this dialectical model the endurance of the system and its active assimilated subjects is indeterminate, although one must not be impatient and underestimate its durability over time. In the strict materialist sense subjectivity might well be an illusion, but it is an illusion that shapes the individual's cognition, comportment and sensibilities down to the tumultuous neurology of the material being itself. This is how, in this difficult and traumatic circular-dialectical process, the subject can recreate itself. The transcendental self must believe itself into a real existence as it appears to itself (Zupančič, 2000; Žižek, 2006), and here is the partial agreement with vitalism and existentialism, apart from the vital caveat that experience and ideology shape the neurological system in ways that form drives and construct desires and fears that influence and restrict choice until that experience and ideology can be transcended and replaced. We are indeed condemned and driven by our material nature to be free, but becoming so is still an extremely difficult task; so precarious, traumatic and daunting that it can be hi-jacked by fake ideologies that offer comforting alternatives and easier routes to a double illusion of subjective and social-ideological change. This reinforces our earlier critique of orthodox liberal theory, which is predicated on the myth of innate and fully-functioning autonomy, rationality and creativity, but bedevilled by its underestimation of the formative subjectifying power of ideology, which, currently dominated by 'capitalist realism', the doctrine that there is no real alternative (Fisher, 2009). Capitalist realism is constantly diffused by the advertising and mass media 
industries, imposing an ideal order on the material substance of the proto-subject and producing a procession of fakes of the alternative symbolic orders and reconstitutive returns whose genuine forms could -if we could once again learn to take them seriously- transform subjectivity. Consumer capitalism, having learnt its techniques of imagery from past religious ideologies, takes advantage of the inescapable ontological fact that the proto-subject is universally characterised by flexibility, tension, lack and anxiety in its material substance and thus needs above all else to enter a cohesive symbolic order. If the two alternative paths away from the terror of the infant's original condition of helplessness are the stupid solipsistic comfort of primary narcissism or the risky identification of the split ego with alienating external signs, merging the two and producing political and subjective inertia alongside an economically powerful illusion of freedom and proliferating enjoyment has been consumer capitalism's most stunning triumph in the twentieth century (Hall et al, 2008). With such a direct correspondence between the internal ideal ego of the self mirrored in the primary other and the ego ideal of the self mirrored in the social other, the selfish, solipsistic narcissist and the other-directed sociable self, and all variations in between, are equally incorporable, as evidenced by current cultural forms that seem to have achieved an impossible fusion between consumer addiction, competitive solipsism and tribal affectivity. Thus the dismal apolitical scenes during the recent consumer riots.

\section{Conclusion}

From symbolic interactionism to Derridean deconstruction and Foucauldian discursivity, all contemporary idealist theories fail, because in their efforts to supersede Hegel they have set up a straw man, the subject as 'one in which self-consciousness is capable of achieving a perfect transparency to itself, of reflexively transubstantiating itself from the opacity of finite immanence into the clarity of infinite transcendence' (Johnston, 2008: 221). For Žižek (2000), Hegel was well aware that there is no clear reflection, and that the potential for the free subject is the stain on the Lacanian mirror, the spot where the symbolic order cannot reflect back its controlled ideological symbols towards the subject, a point at which the subject can take its cue to immerse itself in another transformative encounter with the raw creative energy in its hollow core. The crucial shift into subjectivity is from death-driven negativity, seeking and welcoming an imposed order of operative ideological symbols, to a self-relating negativity that can transcend creatively both its natural and cultural surroundings. Liberal theories, whether discursive/constructivist or autonomist, which posit either a hollow malleable immaterial subject or a natural autonomous subject upon which a subjectifying and normalising order is imposed by an external power without authorisation or solicitation, are missing the point. Initially the distressed subject-in-itself, the victim of a natural and foundational vortex of conflicting drives, can do nothing but crave unary order, authority and identification, which it must later transcend by confronting once again and moving through the gaps in which subjectivity is possible. Lippens (op. cit.) is unerringly right that 'one must relinquish all radical escape from law and code', but there is more. One must actively solicit the symbolic order's principle to pass through it, use its own symbolic tools against it and return to the site of material flexibility to reactivate the processes of subject-formation. If we avoid this, we can create nothing, and all we can do is grunt and rage or, when we tire of that, twist our faces into a cynical sneer. We might have to add another layer underneath the old psychoanalysts' joke. Before the light-bulb will allow itself to be changed, it not only has to want to change but want to become trapped in its official reflection before it can understand what 'change' and 'itself' actually mean. Nobody said it would be easy.

\section{References}

Adorno, T. (1973) Negative Dialectics, trans. E. B. Ashton. London: Routledge \& Kegan Paul

Badiou, A. (2002) Ethics: An essay on the understanding of evil. London: Verso

Badiou, A. (2007) The Century. Cambridge: Polity

Blackmore, S. (1999) The Meme Machine. Oxford: Oxford University Press

Bosteels, B. (2010) 'The Leftist Hypothesis: Communism in the age of terror', in Douzinas, C. \& Žižek, S. The Idea of Communism. London: Verso.

Bull, M. (2000) 'Where is the Anti-Nietzsche'? New Left Review, 3: May/June, 121-45 
Damasio, A. (2003) Looking for Spinoza: Joy, Sorrow, and the Feeling Brain. Orlando, Fla: Harcourt

Dawkins, R. (1989) The Selfish Gene, 2nd Edition. Oxford: Oxford University Press

Dean, J. (2009) Democracy and Other Neoliberal Fantasies: Communicative capitalism and Left politics. Durham, NC: Duke University Press

Dews, P. (2008) The Idea of Evil. Oxford: Blackwell

Ferrell, J. (2007) 'For a ruthless cultural criticism of everything existing'. Crime, Media, Culture, 3(1): 91-100

Fisher, M. (2009). Capitalist Realism: Is there no alternative? Alresford: 0 Books.

Frank, T. (1997) The Conquest of Cool: Business culture, counterculture and the rise of hip consumerism. Chicago: University of Chicago Press

Giddens, A. (1984) The Constitution of Society: Outline of the theory of structuration. Berkeley: University of California Press

Hall, S. (2000) 'Paths to Anelpis: Dimorphic violence and the pseudo-pacification process', Parallax, 6(2): 3653

Hall, S. (2007) 'The Emergence and Breakdown of the Pseudo-Pacification Process', in K. Watson, (ed.) Assaulting the Past. Newcastle upon Tyne: Cambridge Scholars Press

Hall, S. (forthcoming 2012) Theorizing Crime and Deviance: A new perspective. London: Sage

Hall, S., Winlow, S. and Ancrum, C. (2008) Criminal Identities and Consumer Culture: Crime, exclusion and the new culture of narcissism. Cullompton: Willan

Hegel, G. W. (1979) Phenomenology of Spirit. trans. A.V. Miller, Oxford: Oxford University Press

Hobsbawm, E. (1994) The Age of Extremes: The Short Twentieth Century 1914-1991. London: Penguin

Jameson, F. (2010) Valences of the Dialectic. London: Verso.

Johnston, A. (2008) Žižek's Ontology: A transcendental materialist theory of subjectivity. Evanston: Northwestern University Press

Lippens, R. (2012) 'Radical Sovereignty and Control Society: Images of late modern sovereignty in Rebeyrolle's Le Cyclope', Crime, Media, Culture, 8(1) doi:10.1177/1741659011433365

Marx, K. (1842) 'Debates on Law on Thefts of Wood', Rheinische Zeitung, 298, 300, 303, 305 and 307.

Marx, K. (1963) The Eighteenth Brumaire Of Louis Bonaparte. New York: International Publishers

Mill, J. (2006) On Liberty. London: Penguin

Nussbaum, N. (1992) 'Human functionings and social justice: in defense of Aristotelian essentialism', Political Theory 20: 202-46.

Pannakoek, A. (1975) Lenin as Philosopher. New York: Breakout Press

Pippin, R.B. (2011) Hegel on Self-Consciousness: Desire and death in the Phenomenology of Spirit. New Jersey: Princeton University Press

Rasmus, J. (2010) Epic Recession: Prelude to Global Depression. London: Pluto

Rose, J. (2002) The Intellectual Life of the British Working Classes. London: Yale Nota Bene 
Smart, B. (2010) Consumer Society. London: Sage

Turner, C. (2010) Investigating Social Theory. London: Sage

Žižek, S. (2000) The Ticklish Subject: The absent centre of political ontology. London: Verso

Žižek, S. (2006) The Parallax View. Cambridge, MA: MIT Press

Žižek, S. (2010a) Living in the End Times. London: Verso

Žižek, S. (2010b) 'How to Begin from the Beginning', in Douzinas, C. \& Žižek, S. (eds.) The Idea of Communism. London: Verso

Zupančič, A. (2000) Ethics of the Real: Kant, Lacan. London: Verso 